Rita Temmerman*

\title{
Questioning the univocity ideal. The difference between socio-cognitive Terminology and traditional Terminology
}

\begin{abstract}
In this article we are questioning the univocity ideal of traditional Terminology. We show how traditional Terminology in line with Saussurian structuralism ignores part of the interplay between the elements of the semantic triangle. Cognitive semantics and functional linguistics have offered an alternative for the Saussurian structuralist approach. Several of their findings can be of use for the development of socio-cognitive Terminology.

In the LSP of the life sciences, the structure of concepts reflects their epistemological function. This could have consequences for the principles and methods of terminological description. While some concepts (like intron ) are clear-cut and can therefore be submitted to the principle of univocity, others (like blotting and biotechnology) have prototype structure. For prototypically structured categories univocity can not be the aim as polysemy, synonymy and figurative language are part of their naming history.
\end{abstract}

The semantic triangle which was introduced by Gomperz (1908) (Felber, 1984:100) has been referred to by Wüster in $1956^{1}$ (Dreiteiliges Wortmodell (Wüster, 1991:165; in English translation: Felber, 1984:100)), the founder of the Vienna school of Terminology. What is basically explored in this triangular model is the relationship between some kind of reality (the world), a means to communicate about and to create this reality (language), and the centre of reasoning about and of understanding both the world and language (the human mind). (figure 1)

1 Other authors who made reference to the semantic triangle are Ogden (1923), Ullmann (1952), Knobloch (1956), Baldinger (1959)).

* Rita Temmerman

Erasmushogeschool

B-Brussels. 


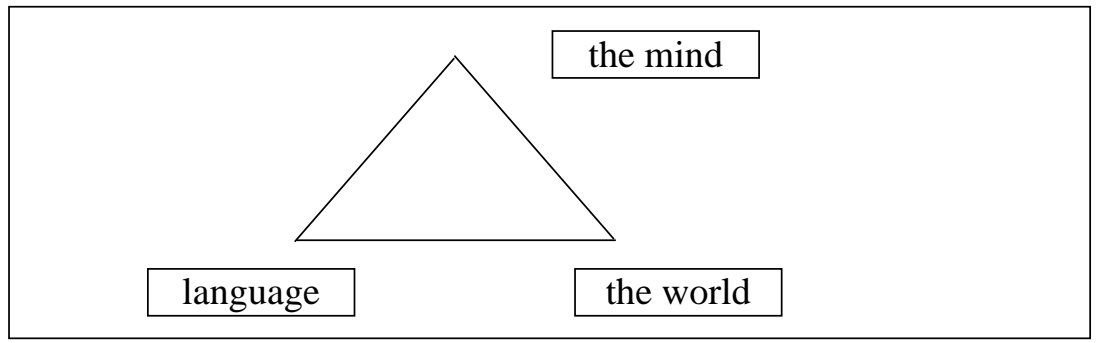

Figure 1: The semantic triangle

Wüster's interpretation of the elements at the three vertices are: "Gegenstand (Sachverhalt)", "Lautkörper" and "Wortinhalt" translated by Felber into individual object, symbol and concept. (figure 2)

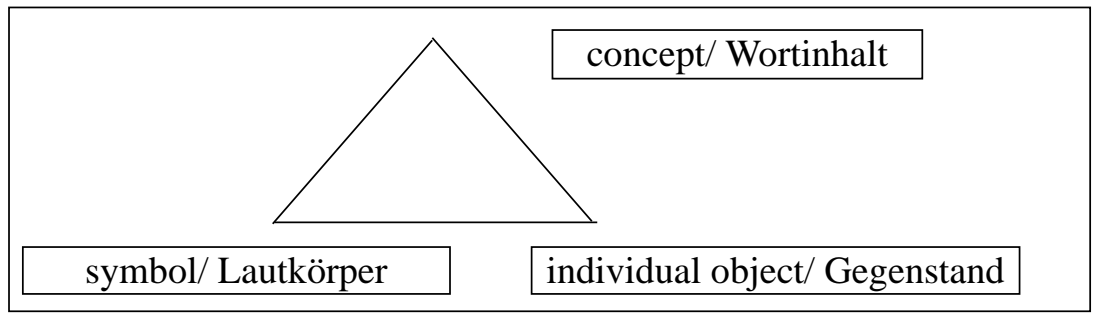

Figure 2: Wüster's Dreiteiliges Wortmodell

In what follows we shall try and compare the filling in of these three elements in traditional Terminology and in a new theory of Terminol${ } \mathrm{gg}^{2}$ we should like to propose here which opts for a different theoretical framework being strongly inspired by the insights of cognitive semantics and functional linguistics.

This new socio-cognitive theory of Terminology reacts against the theoretical framework which underpins the procedures and methods of Terminology as traditionally defined, perceived and established by Wüster and his successors by means of a set of guiding principles as from 1959 (Laurén \& Picht, 1993). The same theoretical framework was largely shared by the allegedly different schools of Terminology (the Soviet school, the Prague school, the Canadian centre, etc.) This is

2 We distinguish between Terminology and terminology. Terminology (capitalised) refers to the theory underlying and resulting from the study of terminology, the vocabulary of LSP (Language for Specific Purposes). 
understandable as on the one hand all the Terminology schools underwent the influence of the leading trend in linguistics at the time of their heydays: Saussurian structuralism; and on the other hand the underlying motivation for each of the Terminology schools seems to be language planning. In more detail this involves that: one, Saussurian structuralist semantics believed that (words have) meanings (that) can be clearly delineated. The European (as opposed to the Canadian) terminology model starts from the belief that a concept, that will be given the status of the 'meaning' of the term that will be assigned to it, can and should be clearly delineated.

Two, Saussurian structuralist semantics believes that the best way to describe meaning is to describe the mutual delimitation of concepts (semantic relations). Traditional Terminology believes that the best way to describe concepts is to determine their position in a concept system which visualises logical and ontological relationships. On the basis of the position in the concept system a definition will be formulated.

Three, Saussurian structuralist semantics believes that the best way to describe meaning is to concentrate on denotational meaning (as opposed to connotational meaning) and on the literal meaning (and not the figurative meaning) of words. Traditional Terminology believes that the concept system is to be seen as independent from the term system, and that consequently, unlike words, terms are context independent: the meaning of the term is the concept.

Four, Saussurian structuralist semantics believes that meaning is to be described synchronically. For traditional Terminology language development and language evolution need not be studied as the main emphasis is on the concept system. Therefore terminology is synchronic.

Five, it is significant that the underlying motivation for each of the Terminology schools seems to be language planning. For the Prague, the Soviet and the Vienna schools there is a strong orientation towards standardisation. The Vienna school has the conviction that it is possible to influence the naming activities in LSP, and the Canadian centre has the specific aim to secure the survival of the French language in Canada. One can imagine how difficult it is to question the principles and methods of terminological meaning description if the underlying motivation for the claimed scientific schools is language planning, which implies sponsoring by governmental bodies with language political objectives. The outcome is that the scientific study of Terminology 
is confounded with establishing principles and methods for the pragmatic activity of standardisation.

The new socio-cognitive theory of Terminology emphasises that Terminology should not be uniquely oriented towards standardisation and it questions the validity of objectivism as the theoretical underpinning of terminology.

\section{The objectivist model of traditional Terminology}

In traditional Terminology the full potential of the three elements of the semantic triangle was deliberately not explored nor exploited.

The world was reduced to what could be objectified, language was only considered in its naming capacity, and the human mind was only given credit for its capacity to classify individual objects on the basis of recognising characteristics which were common to all the members of the class representing a concept.

The relationship between the world and language was limited to the acceptance that the world is objectively given and has to be named.

The relationship between the world and the mind was reduced to the fact that the world can be understood by the human mind thanks to the classificatory capacity of the mind.

For as far as the relationship between language and the mind is concerned, the fact that language may have a role to play in the mental activity of understanding the world, in other words the creative potential of language is not ignored, but disregarded, brushed aside as irrelevant.

Underlying all this is logical positivism's belief that for clear thinking natural language is an obstacle. A calculus, i.e. a formal axiomatic system, would be ideal. In formalising an existing axiomatic system variables are replaced by meaningless symbols. In doing so one obtains a logical system without meaning which allows for the objectification of several purely formal deductions. A calculus allows for a sum up of existing theoretical systems in short symbolic representations which permits more insight in the purely logical relations between diverse statements. Natural language is treated as a necessary evil which one tries to constrict. One example of such attempts at constriction is standardisation of terminology. Standardisation equals a strife for univocity. One concept is referred to by one term (no synomymy) and one 
term can only refer to one concept (no polysemy). Polysemy, which is a characteristic of natural language is treated as uneconomical and therefore steps need to be taken to curtail the phenomenon. Language is reduced to the conscious literal level. Figurative language and connotative language are disregarded. Language is not to be seen as a process in time. What is aimed at is a synchronic language description.

\section{The integrated model of modern Terminology}

Modern socio-cognitive Terminology can benefit from the findings of cognitive semantics which elaborates on the full potential of the interaction between the world, language, and the human mind; and from the insight that the elements of the semantic triangle function in a social setting.

Cognitive Terminology considers the world of science and technology as experiential. Much of what we know and understand about the world is embodied, is the result of our sensory perceptions. It should be added that the other part is the result of our reasoning, which is interactive with the input via sensory perception, and via the transfer of other language users' ideas which we take in via discourse (written and spoken) for which language is the medium.

Language has a cognitive function (ideational), next to a textual and a communicative (interpersonal) function. (Halliday, 1985). Language is a means for categorisation. ${ }^{3}$

Modern Terminology could incorporate the idea that humans do not just perceive the objective world but have the faculty to create categories in the mind. Many of these categories in the mind have prototype structure.

Prototype-theory finds its origin in the work of psychologist Rosch. Her hypothesis is that the human being has a prototype, a best example for each category, in his mind and that classification happens on that basis. In Women, Fire and Dangerous Things, Lakoff (1987) proves that the categorisation of things does not happen exclusively on the basis of common features. His hypothesis is that human observation is deter-

3 Note the distinction between on the one hand logical and ontological classification, which in traditional Terminology is supposed to be possible in the mind without considering or using language and before the naming of the concepts takes place, and on the other hand categorisation which is a result of the interaction between language and the mind. 
mined by the possibilities and restrictions of the human body and is culturally determined. Rosch studied prototypes via configurations of features, which helped her to understand the structure of the categories in the mind. Exemplars of the category 'bird' can have features like 'is able to fly', 'has feathers', 'has a beak', 'is not a pet', 'lays eggs' etc. There is no need for one or more features which are shared by all the exemplars of a category. Exemplars belong to a category because they show resemblance and share different sets of features. The exemplars can be seen as members of one family. The exemplars of the category have family-resemblance.

As far as the relationship between the world and language is concerned, language is the medium for expressing human world perception and human world conception. Language plays a role in the human understanding of the world.

Looking at the relationship between the world and the mind sociocognitive Terminology considers the world to be (partly) in the human mind. When considering language and mind, socio-cognitive Terminology is ready to accept that the understanding of language cannot be separated from the understanding of the world.

\begin{tabular}{|c|c|c|}
\hline & traditional Terminology & $\begin{array}{l}\text { socio-cognitive } \\
\text { Terminology }\end{array}$ \\
\hline the world and language & $\begin{array}{l}\text { the world exists objectively } \\
\text { and can be named }\end{array}$ & $\begin{array}{l}\text { language plays in the } \\
\text { understanding of the world }\end{array}$ \\
\hline the world and the mind & $\begin{array}{l}\text { the world can be understood } \\
\text { by the human mind thanks } \\
\text { to the classificatory capacity } \\
\text { of the mind }\end{array}$ & $\begin{array}{l}\text { the world is (partly) in the } \\
\text { human mind }\end{array}$ \\
\hline language and the mind & $\begin{array}{l}\text { the creative potential of lan- } \\
\text { guage is disregarded }\end{array}$ & $\begin{array}{l}\text { the understanding of lan- } \\
\text { guage can not be separated } \\
\text { from the understanding of } \\
\text { the world }\end{array}$ \\
\hline
\end{tabular}

Figure 3: The interpretation of the relationships between the world, language and the mind in traditional Terminology and in socio-cognitive Terminology.

In conclusion we can say that for socio-cognitive Terminology the explanatory power of the full potential of how all three elements of the semantic triangle interact is of importance in studying terminology. 


\section{Distinction between types of concepts based on diffe- rences in interaction between the three elements in the seman- tic triangle}

Geeraerts (1993:58-63) explains how cognitive semantics links up the empiricist position that "experience determines conceptuality" (58) and the rationalist idea that "conceptual knowledge determines experience" (58).

"On the one hand experientialism demonstrates how experiential factors shape the structure of cognition; on the other hand, paradigmatism points out how existing conceptualizations may influence the interpretation of new experiences." (58)

In this analysis, existing concepts have an influence on how we shape new experience. Next experiences are interpreted in terms of and integrated with existing concepts; Geeraerts has proved that the structure of our concepts reflects their epistemological function. He distinguishes between two types of prototypically structured categories: cognitive categories and ontological categories (Geeraerts, 1989a:74-79)(see also Zawada \& Swanepoel, 258-61)

As an example of a cognitive category he gives Dutch "vers" (= fresh, recent), Dutch "vogel" (bird) is an ontological category. In the following scheme (figure 4)(Geeraerts, 1989a:78) he compares the two types of categories on four parameters: psychological status, typical relationships, explanatory factors for the prototype structure and the principle of cohesion.

\begin{tabular}{|l|l|l|}
\hline & ontological categories & cognitive categories \\
\hline example & "vogel" & "vers" \\
\hline psychological status & not ambiguous & ambiguous \\
\hline typical relationships & non-figurative resemblance & all associative relations \\
\hline $\begin{array}{l}\text { explanatory factor for } \\
\text { the prototype structure }\end{array}$ & materialistic factors & functional factors \\
\hline principle of cohesion & presumed identity & interpretative association \\
\hline
\end{tabular}

Figure 4: Geeraert's comparison between ontological and cognitive categories on four parameters. 
In what follows we want to show first that in the LSP of the life sciences, the structure of concepts reflects their epistemological function and that this could have consequences for the principles and methods of terminological description. We shall give examples of terminological units which are more fit for a description in line with the TC $37^{4}$ terminology concept approach for terminology while for others it is better to consider them in line with the experiential category approach. In the second place we want to show that for prototypically structured categories the claimed functional advantage of univocity is an delusion.

Geeraerts comparison between two types of prototypically structured categories (cognitive categories and ontological categories) in LGP may be of theoretical relevance in studying the vocabulary of LSP as well (and this contrary to the convictions of traditional Terminology). In studying the epistemological function of categories in the domain of the life sciences, we found out that it makes sense to first of all distinguish between concepts/categories which do not have prototype structure and concepts/categories which do.

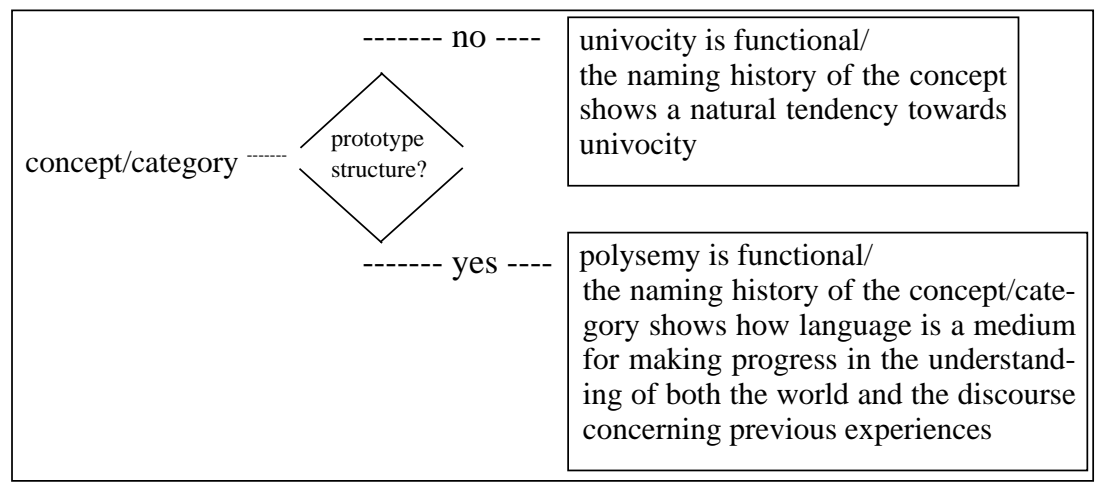

Figure 5: The naming history of a prototypically structured concept/category differs from the naming history of a non-prototypically structured concept/ category.

Elsewhere we showed (Temmerman,1996c) how an in-depth contrastive study of the intension and the extension of three concept/

4 Technical Committee 37 of the International Standardisation Organization is responsible for international standards concerning the principles and methods for terminological description. 
categories $^{5}$ occurring in the LSP of the life sciences shows different requirements and possibilities for definitions. A concept/category like intron can be defined in accordance with the traditional terminological principles and methods as it is a logical concept/category. For the concepts/categories of the type techniques (for which we give the example of blotting) this is less possible and for an umbrella concept/ category like biotechnology not at all. An umbrella concept/category like biotechnology meets all the requirements for intensional and extensional prototypicality as described in cognitive semantics. (Geeraerts, 1989; Taylor,1989; Kleiber, 1990) With reference to Geeraerts classification (figure 4) blotting has most of the characteristics of an ontological category of the "vogel" type, while "biotechnology" bears more resemblance to a cognitive category of the "vers" type. For details we refer to Temmerman (1996c).

For our present purpose it will suffice to briefly introduce these three concepts/categories and to show figures 7 and 8 from which it will be clear that a comparison of the intension and the extension of the three concepts/categories in the traditional model and in the alternative prototype model shows that concept/categories which show prototype structure cannot be adequately defined and described on the basis of the principles and methods of the Vienna school for terminology.

We shall first provisionally introduce the three concepts by quoting a definition from a specialist source.

\section{- The first concept/category is intron}

Gilbert discovered in 1978 that genes are split, i.e. that they have a structure in which the coding sequences and the non coding sequences interlace

"By the late 1970s, it was clear that the protein-coding sequences in a eukaryotic gene do not necessarily consist of a single continuous stretch of $D N A$, as they do in a bacterial gene. Instead the coding region is often discontinuous, being interrupted by stretches of noncoding DNA; such noncoding DNA segments are called intervening sequences or introns, and the coding segments of genes - those that generally direct polypeptide synthesis - are referred to as exons" (Berg \& Singer,1992:126)

5 As concept is used in traditional Terminology and category in cognitive semantics and as we are comparing the possibilities and limitations of both approaches we prefer not to choose for either one or the other denomination but to refer to the problem as concept/category. 


\begin{tabular}{|l|l|l|l|l|l|}
\hline exon & intron & exon & intron & exon & intron \\
\hline
\end{tabular}

Figure 6: The structure of eukaryotic DNA.

\section{- The second concept/category is blotting}

For geneticists it is often useful to be able to identify a particular sequence in DNA fragments separated by gel electrophoresis. In $1975 \mathrm{E}$. M. Southern developed a method for doing so. Later, blotting of RNA and protein was carried out and named by (false) analogy Northern blotting and Western blotting. Methods for identifying both DNA and protein are called South-Western blotting, for both RNA and protein North-Western blotting.

The Dictionary of Microbiology and Molecular Biology (1987) has the following entry for blotting:

"Following ELECTROPHORESIS: the transfer of nucleic acids and/or proteins from a gel strip to a specialized, chemically reactive paper (or other matrix) on which the nucleic acids etc. may become covalently bound in a pattern similar to that present in the original gel. Transfer may be effected by capillary action - in which case paper (e.g. nitrocellulose, DEAE paper, APT paper) is sandwiched between the gel and a highly absorptive pad;

alternatively, in electro-blotting, transfer is effected by electrophoresis. In the earliest (capillary) blotting, DNA was transferred to nitrocellulose (in the so-called 'Southern blot' or SOUTHERN HYBRIDIZATION procedure; subsequently, blotting of RNA (Northern blot) and protein (Western blot) was carried out. After blotting, a particular target molecule may be identified or assayed e.g. by fluorescence labelling or enzyme immunoassay techniques."

\section{- The third concept is biotechnology}

Biotechnology is "the application of advanced biological techniques in the manufacture of industrial products, including the production of antibiotics, insulin and interferon, or for environmental management, such as waste recycling” (Academic Press Dictionary of Science and Technology, 1992)

"Biotechnology took on a new meaning and focus with this novel power to use DNA as a tool to make marketable materials. Modern biotechnology can be defined in its most general sense as the scientific manipulation of organisms, particularly at the molecular genetic level, to produce useful products. In a sense, biotechnology is one of the oldest industries in the 
world. The fermentation of wine or the preparation of bread, both brought about through the metabolic activities of yeast, come under its rubric, as do the centuries of cross-breeding and hybridization of crops and domesticated animals." (Lee, 1993:16-17)

\begin{tabular}{|l|l|l|l|}
\hline \multirow{2}{*}{} & \multicolumn{2}{|l|}{ intension } & extension \\
\cline { 2 - 4 } & superordinate concept & $\begin{array}{l}\text { characteristics to deline- } \\
\text { ate from other concepts } \\
\text { on the same horizontal } \\
\text { level }\end{array}$ & $\begin{array}{l}\text { possible to enumerate } \\
\text { all species or all indi- } \\
\text { vidual objects }\end{array}$ \\
\hline intron & yes & yes & yes \\
\hline blotting & $\begin{array}{l}\text { a multitude of pos- } \\
\text { sible superordinate } \\
\text { concepts }\end{array}$ & $\begin{array}{l}\text { encyclopaedic in- } \\
\text { formation is defi- } \\
\text { ning the concept// } \\
\text { category }\end{array}$ & $\begin{array}{l}\text { yes, but other infor- } \\
\text { mation is more rele- } \\
\text { vant }\end{array}$ \\
\hline biotechnology & no & no & no \\
\hline
\end{tabular}

Figure 7: The feasibility of a definition in line with the principles and methods of traditional terminology for three concepts.

\begin{tabular}{|l|l|l|l|l|l|}
\hline \multicolumn{2}{|c|}{} & \multicolumn{2}{|l|}{ intensionally } & \multicolumn{2}{l|}{ extensionally } \\
\cline { 2 - 6 } & \multicolumn{2}{|l|}{$\begin{array}{l}\text { clustering of } \\
\text { senses into fam- } \\
\text { ily resemblance } \\
\text { and radial sets }\end{array}$} & $\begin{array}{l}\text { absence of defi- } \\
\text { nitions in terms } \\
\text { of necessary and } \\
\text { sufficient attri- } \\
\text { butes }\end{array}$ & $\begin{array}{l}\text { differences of sa- } \\
\text { lience among } \\
\text { members of the } \\
\text { category }\end{array}$ & $\begin{array}{l}\text { fluctuations at } \\
\text { the edges of the } \\
\text { family }\end{array}$ \\
\hline entity & intron- & no & no & no & no \\
\hline technique & blotting & no & yes & yes & no \\
\hline $\begin{array}{l}\text { umbrella } \\
\text { term }\end{array}$ & $\begin{array}{l}\text { biotech- } \\
\text { nology }\end{array}$ & yes & yes & yes & yes \\
\hline
\end{tabular}

Figure 8: Four characteristics of prototype structure in three types of categories

Intron can be defined in a logical concept structure, but blotting and biotechnology cannot.

Based on our insights gained in studying three types of concepts in the vocabulary of the life sciences we believe we can formulate the following propositions:

One, when new phenomena are discovered which can be clearly delineated and defined there is a natural development towards univocity 
which in that case appears to be in favour of unambiguous and therefore efficient communication (3.1).

Two, univocity as the ideal for unambiguous and therefore efficient reasoning and communication can not be defended for the prototypically structured categories (3.2). This has at least three aspects to it. First polysemy is functional in LSP. It is the consequence of meaning evolution. The constant discussion over how to name and what words mean is in the discourse of a community and implies language evolution. Polysemy is the result. What is univocal at one time may grow into polysemy depending on the type of concept/category and how it is understood (3.2.1). Second (near-) synonymy exists for very good reasons (3.2.2). Third, figurative language is a motor which causes the thoughts and consequently the understanding of the world to move (3.2.3).

\subsection{When new phenomena are discovered which can be clearly delineated and traditionally defined 6 there is a natural development towards univocity which in that case favours un- ambiguous and therefore efficient communication}

An indication that for clear-cut concepts/categories like intron, which do not show characteristics of prototypicality, univocity is indicated is in the natural tendency towards standardisation as it can be observed in the discourse of the scientists at the time of the discoveries. Once the definition is agreed upon, the naming is negotiated and there is a tendency to try and rule out synonymy. The order of things is in accordance with the principles and methods for standardisation.

We can prove this with the example of the birth of the concept/ categories intron-exon. The case of intron-exon is a case of naming negotiation.

We went to the articles which were published in the leading periodicals Nature and Science in 1978 and 1979 when the phenomenon of the intron-exon structure of eukaryotic genes was being discovered. We consider these articles in chronological order:

6 By traditional definition we mean the type of definition based on logical or ontological (partitive) classification, giving the superordinate term and enumerating the necessary and sufficient characteristics which delineate the concept under consideration from other related concepts on the same horizontal level. 
Three authors were publishing on the intron-exon structure of eukaryotic genes:

1. Walter Gilbert, who was then American Cancer Society Professor of Molecular Biology at Harvard University, published a short article entitled: "Why genes in pieces?" Nature, 9 Feb. 1978:501.

2. W. Ford Doolittle, was Associate Professor in the Department of Biochemistry, Dalhousie University, Halifax, Nova Scotia, when he published the article "Genes in pieces: were they ever together?" Nature, 13 April 1978:581-82.

3. Francis Crick wrote the article 'Split Genes and RNA Splicing.' Science, 20 April 1979, 264-71, when he was Kieckhefer Research Professor in La Jolla, California.

In their articles they discuss the terminology. First we should make it clear that the facts are agreed upon: there is a consensus that eukaryotic genes have alternating stretches of coding and non-coding DNA. Second, we find evidence in the scientific literature that suggestions are given by the authors for the naming of three concepts/categories (split genes, intron and exon). The core definition for each of these concepts/categories is given in figure 9. We shall first pay attention to Gilbert's terminology.

'Our picture of the organisation of genes in higher organisms has recently undergone a revolution. Analyses of eukaryotic genes in many laboratories 1-10, studies of globin, ovalbumin, immunoglobulin, SV40 and polyoma, suggest that in general the coding sequences on DNA, the regions that will ultimately be translated into amino acid sequence, are not continuous but are interrupted by 'silent' DNA. Even for genes with no protein product such as the tRNA genes of yeast and the rRNA genes in Drosophila, and also for viral messages from adenovirus, Rous sarcoma virus and murine leukaemia virus, the primary RNA transcript contains internal regions that are excised during maturation, the final tRNA or messenger being a spliced product.

The notion of the cistron, the genetic unit of function that one thought corresponded to a polypeptide chain, now must be replaced by that of a transcription unit containing regions which will be lost from the mature messenger-which I suggest we call introns (for intragenic regions)-alternating with regions which will be expressed-exons. The gene is a mosaic: expressed sequences held in a matrix of silent DNA, an intronic matrix. The introns seen so far range from 100 to 10,000 bases in length; I expect 
the amount of DNA in introns will turn out to be five to ten times the amount in exons." 7

In this text-fragment a conclusion is drawn based on "analyses of eukaryotic genes in many laboratories". The author justifies the 'many' by enumerating 10 references to publications on the subject at the end of the article.

The studies suggest that the coding sequences on DNA are not continuous but are interrupted by "'silent' DNA". Gilbert suggests to call the "regions which will be lost from the mature messenger" "introns (for intragenic regions" and "the regions which will be expressedexons". This is an example of an attempt at coining new terms in a scientific article. It is perfect for illustrating the stimulus-response principle. Gilbert is making reference to 10 other publications, which he has taken into consideration before suggesting names for the newly discovered phenomena ('silent' DNA, 'intron', 'exon', 'introgenic' matrix). His suggested terminology is partly followed by colleagues, like Doolittle and Crick (see further) but what is most interesting is that it is also commented upon and criticised as the fragment from Crick's article shows.(see further).

\begin{tabular}{|c|c|c|c|}
\hline DEFINITION: & $\begin{array}{l}\text { any eukaryotic gene in } \\
\text { which the coding se- } \\
\text { quences are interrupted } \\
\text { by a number of usually } \\
\text { noncoding regions } \\
\text { (Rieger) }\end{array}$ & $\begin{array}{l}\text { base sequences along the } \\
\text { DNA of the gene which } \\
\text { do not appear in the final } \\
\text { mRNA }\end{array}$ & $\begin{array}{l}\text { base sequences on the } \\
\text { DNA which do end up in } \\
\text { the mRNA }\end{array}$ \\
\hline \multirow{3}{*}{$\begin{array}{l}\text { Gilbert, } \\
9 \text { Feb. } 1978 \\
\text { Nature }\end{array}$} & \multirow[t]{3}{*}{ genes in pieces } & introns & exons \\
\hline & & internal regions & \multirow{2}{*}{$\begin{array}{l}\text { regions which will be } \\
\text { expressed }\end{array}$} \\
\hline & & intragenic regions & \\
\hline \multirow{2}{*}{$\begin{array}{l}\text { Doolittle, } \\
13 \text { Apr. } 1978 \\
\text { Nature }\end{array}$} & \multirow[t]{2}{*}{ genes in pieces } & intronic DNA & exonic DNA \\
\hline & & $\begin{array}{l}\text { redundant non-informa- } \\
\text { tional DNA /'inter- } \\
\text { vening' DNA }\end{array}$ & coding DNA \\
\hline \multirow{4}{*}{$\begin{array}{l}\text { Crick, } \\
20 \text { Apr. } 1979 \\
\text { Science }\end{array}$} & \multirow[t]{4}{*}{ split genes } & introns & exons \\
\hline & & intervening DNA & \multirow[t]{3}{*}{ sense DNA } \\
\hline & & internal stretch & \\
\hline & & nonsense DNA & \\
\hline
\end{tabular}

Figure 9: Synonyms in specialist publications for three clearly delineated concepts.

7 The emphasis is mine. 
We shall now consider Doolittle's article. Doolittle refers to Gilbert's terminology:

"The recent discovery that many eukaryotic structural genes are interrupted by stretches (sometimes very long) of non-informational intervening' DNA ${ }^{1-7}$ is the latest and most dramatic demonstration of the striking difference between the organisation of prokaryotic and eukaryotic genomes. (...)

Gilbert has proposed that intervening DNA serves to speed evolution; the mature polypeptide chain is translated from a spliced $m R N A$ derived from a primary transcript of both intronic (non-informational DNA) and exonic (coding) DNA. Occasional imprecise splicing can generate new proteins assembled from parts of old ones without sacrificing the original genes.

(...)

In such cells a genes-in-pieces organisation (with RNA splicing) could not only have its current (evolutionary) role, but an additional role: to ensure that transcripts of exons ( (sic!: this parenthesis is never closed) reiterated but often incorrectly replicated and transcribed were at least occasionally assembled so as to template functional proteins. As replication, transcription and translation became more faithful, such insurance became less necessary and the replication and transcription of redundant and noninformational DNA became increasingly irrelevant and burdensome." 8

In line with Gilbert, to whose point of view Doolittle reacts in this article, Doolittle uses "genes-in-pieces" here, for what in the literature later on is mostly called "split genes". He also uses "exons" and the adjectival derivations from intron and exon: "intronic DNA" and "exonic $D N A$ ". For "intronic DNA" he uses the synonymous, motivated or selfexplanatory terms "redundant and non-informational DNA" and "intervening DNA”.

In Crick's article the most striking new term is "'split' genes" (264).

"In the last 2 years there has been a mini-revolution in molecular genetics.

When I came to California, in September 1976, I had no idea that a typical gene might be split into several pieces and I doubt if anybody else had."

Crick refers to Gilbert 's article, and then, he comments on the terminology:

“... in this case there are two fairly long stretches of base sequences along the DNA of the gene which do not appear in the final mRNA. Such sequences are now known as intervening sequences; An alternative terminology, used by Gilbert and his colleagues refers to the intervening sequences as

8 The emphasis is mine. 
"introns"; those base sequences on the DNA which do end up in the mRNA are referred to as "exons" since they are the ones which are expressed. At this stage, any terminology is likely to lead, before long, to difficulties and complications.(5) In this article I use the intron-exon terminology, if only for want of a better one." 9

In his footnote (5) Crick explains why he finds this terminology confusing:

"There are two main difficulties. A stretch of nuclear RNA may be part of an intron if spliced one way but part of an exon if spliced in another way. In addiction, one is tempted to use the two words to describe the parts of the DNA from which the stretches of RNA are transcribed. Nevertheless, used judiciously, the two words are undoubtedly useful. I imagine some committee will eventually decide on a wholly logical terminology."

Apart from introducing a more general term "split genes" for "genes having an intron-exon structure" or "genes in pieces "(Gilbert), Crick also offers alternative terminology: he talks about "intervening sequences" (like Doolittle) whereas Gilbert calls these "intragenic regions" and uses the opposition " "nonsense" stretches of DNA" "interspersed within the "sense" DNA". Furtherdown Crick introduces another synonym for "intron": "internal stretch" and he links up the concepts of "split genes" and "splicing":

'Thus splicing is defined as the mechanism by which a single functional RNA molecule is produced by the removal of one or more internal stretches of RNA during the processing of the primary transcript.

Where are split genes found?'. (265)

What Crick presents as if it were a problem of lexicalisation (terminology) causing ambiguity which he suggests could be solved by some terminology committee is actually not a terminology problem at all. The fact that the same stretch can be an "intron" in one "context" and an "exon" in another, does not make the terminology unclear as "intron" and "exon" are motivated terms because they express that in a specific situation particular stretches of DNA are not coding or are coding for information.

What we see at work here, is a discussion between field specialists about the best term for concepts/categories, the definition of which they agree upon. The order of things is like in a standardisation procedure: first the concept, then several possible names (synonyms) and a trend towards univocity.

9 The emphasis is mine. 
We also find that Crick is explicitly imposing his authority, which points at the social factors in choosing the preferred term. As the codiscoverer (together with Watson in 1953) of the double-helix structure of DNA he is likely to be taken seriously in academic circles.

\subsection{Univocity as the ideal for unambiguous and therefore efficient reasoning and communication can not be defended for the prototypically structured categories}

The three reasons why univocity is not feasible nor desirable for concepts/categories with prototype structure are represented in figure 10 .

\begin{tabular}{|l|l|}
\hline $\begin{array}{l}\text { The univocity ideal in traditional } \\
\text { Terminology }\end{array}$ & $\begin{array}{l}\text { The alternative view of socio- } \\
\text { cognitive Terminology }\end{array}$ \\
\hline $\begin{array}{l}\text { Univocity aspect 1: a term is not poly- } \\
\text { semous. Terminology takes a synchronic } \\
\text { point of view The dynamic nature of } \\
\text { language is disregarded. }\end{array}$ & $\begin{array}{l}\text { Polysemy is functional in LSP discourse, } \\
\text { it is consequence of meaning evolution } \\
\text { The constant discussion over how to name } \\
\text { and what words mean is in the discourse } \\
\text { of a community and has a time aspect. } \\
\text { olysemy is the result. What is univocal at } \\
\text { one time may grow into polysemy } \\
\text { depending on the type of category and } \\
\text { how it is understood. }\end{array}$ \\
\hline $\begin{array}{l}\text { Univocity aspect 2: a concept should be } \\
\text { referred to by one term only; a term should } \\
\text { not have synonym }\end{array}$ & $\begin{array}{l}\text { Synonymy is functional in LSP discourse; } \\
\text { it reflects different perspectives }\end{array}$ \\
\hline $\begin{array}{l}\text { Univocity aspect 3: literal language can } \\
\text { replace figurative language. }\end{array}$ & $\begin{array}{l}\text { Figurative language is a motor to make the } \\
\text { thoughts move }\end{array}$ \\
\hline
\end{tabular}

Figure 10. This table shows the contrastive stances of traditional Terminology and socio-cognitive Terminology with regard to three aspects of univocity. 


\subsubsection{Polysemy in language is functional. It is the result of the human reflection about the world. From a purely semasi- ological point of view it is the result of meaning evolution.}

We shall illustrate the functionality of polysemy in the progress of the life sciences with the case of molecular cloning. ${ }^{10}$ As the case is quite complicated we suggest to formulate the problem in the following two questions. Question one: why are the methods developed in molecular biology for the amplification of a fragment of DNA named cloning or molecular cloning or DNA cloning or gene cloning? Question two: why has cloning recently been threatened to be replaced by its hyperonym amplification?

The naming of the methods for the amplification of a fragment of $D N A$ cannot be separated from the history of the lexeme clone in general nor from the history of the development of the life sciences (biology, medicine, biochemistry, genetics, molecular biology, biotechnology). Figure 10 is a schematic representation of the meaning extension of the lexeme cloning which entered the English language in 1903, both as a substantive clone and as its derived form cloning, indicating the technique.

10 "molecular cloning - the multiplication of DNA sequences usually involving the isolation of appropriate DNA fragments and their in vitro joining (insertion into a restriction site) to a cloning vector capable of replication when introduced into an appropriate host. M.c. requires: (1) DNA of interest (foreign, passenger, or target DNA); (2) a cloning vector; (3) restriction endonucleases; (4) DNA ligase; (5) a prokariotic or eukaryotic cell to serve as the biological host." (Rieger, 1991:333). 


\begin{tabular}{|c|c|c|}
\hline \multicolumn{3}{|l|}{ CLONING } \\
\hline since when & what is cloned & method \\
\hline $\begin{array}{l}\text { since the beginning of agri- } \\
\text { culture; named as such in } \\
\text { English in } 1903 \text { (Webber) } \\
\text { (source Rieger) }\end{array}$ & plants & $\begin{array}{l}\text { cutting } \\
\text { grafting }\end{array}$ \\
\hline 1929 (source: Barnhart) & bacterial cells & cell cultivation \\
\hline 1939 (Smith:1988) & $\begin{array}{l}\text { plant cells in order to } \\
\text { achieve full plants }\end{array}$ & $\begin{array}{l}\text { cell cloning and regene- } \\
\text { ration }\end{array}$ \\
\hline $\begin{array}{l}\text { late 1940s (Levine and } \\
\text { Suzuki, 1993:183) }\end{array}$ & amphibians & enucleation \\
\hline $\begin{array}{l}1973 \text { (Cohen et al., 1973, } \\
\text { source: Rieger) }\end{array}$ & DNA & $\begin{array}{l}\text { molecular cloning } \\
\text { (gene splicing }+ \text { bacterial } \\
\text { cell cloning) }\end{array}$ \\
\hline $\begin{array}{l}1985 \text { (by Saikai, according } \\
\text { to Rieger; by Karry Mullis } \\
\text { according to Watson et al., } \\
1992: 79 \text { ) }\end{array}$ & DNA & $\begin{array}{l}\text { PCR (polymerase chain } \\
\text { reaction) }\end{array}$ \\
\hline \multirow[t]{2}{*}{1988 (Hawkes,1991:15) } & mammals & embryo splitting \\
\hline & mammals & nuclear transplantation \\
\hline
\end{tabular}

Figure 10: The development of cloning.

The reply to the first question why molecular cloning was named as such has at least the following three aspects:

One, because molecular cloning related to the other types of cloning which had existed for a long time already when molecular cloning was developed

Two, the relevant meaning element which molecular cloning had in common with all the other types of cloning which existed already was 'identical copy'. The new element which was added to the meaning of clone because of molecular cloning was large number of identical copies'. 11

11 "The cloning of a fragment of DNA allows indefinite amounts to be produced from even a single original molecule. (A clone is defined as a large number of identical cells or molecules, all identical with an original ancestral cell or molecule.) The property that makes cloning of DNA possible is the ability of bacterial plasmids and phages to continue their usual life-style after additional sequences of DNA have been incorporated into their genomes." (Lewin, 1983:300). 
Three, molecular cloning was named as such because it is a next step in the evolution of molecular genetics. This in contrast with PCR (polymerase chain reaction). (see further).

The reply to the second question why cloning threatened to be replaced by amplification is twofold.

One, a new method for making large numbers of exact copies is developed, not in the molecular genetics line but in the enzymology or biochemistry line: polymerase chain reaction (PCR). Some writers refer to PCR as a special type of cloning whereas others would rather see it as a method for amplification, the hyponym of both cloning and $P C R$. (see further);

Two, cloning threatened to be replaced by amplification in the terminology of the life sciences as a consequence of the phenomenon of generic posting. The further development of language in other domains of life had its repercussions. On the one hand cloning was metaphorically borrowed by LGP. As the lexeme is used in more and more domains of life it may have become overloaded ${ }^{12}$. As a consequence it is likely to become confusing (because of too vague) in its scientific context and since synonyms and hyperonyms exist it will predictably be replaced by one of these. This is the case for cloning in its molecular cloning or gene cloning sense. The term we find it replaced by in the LSP literature is mostly amplification.

The lexeme clone and cloning not only become overloaded as a consequence of polysemy, they also start suffering from ambiguity. Gene cloning, which literally stands for the procedure to produce a large number of copies of a particular gene, also ends up being used for the totality of a new discipline (which involves more and more new techniques under development as well) and for the aspect of the gene cloning procedure which made the procedure worthwhile (gene splicing). So the term gene cloning is used at the same time in its literal sense, as a pars pro toto and as a toto pro pars, which obviously amounts to ambiguity.

We shall look at the twofold reply to question two in more detail. First we describe the coming into existence of the new technique for making large numbers of exact copies: polymerase chain reaction (PCR), then we shall illustrate the generic posting phenomenon.

12 Overloaded terms or words are used in too many different senses (Meyer,1992:31). 
What is PCR? PCR (polymerase chain reaction) is a technique developed in 1985 "which enables selective amplification of DNA sequences" (Nicholl, 1994:100), but which is based on different principles and a process very different from molecular cloning.

"The polymerase chain reaction $(P C R)$ is an in vitro method for selectively amplifying, or synthesizing millions of copies of a short region of a DNA molecule. The reaction is carried out enzymatically in a test tube..." (Cooper, 1994:128)

The meaning components 'cloning' and 'PCR' have in common are 'amplification' and 'identical copies'. As before the development of PCR there was only one technique ( be it in many different procedures or methods) for amplification of DNA sequences, i.e. 'cloning' with vectors in host cells, the terms 'amplification' and 'cloning' were synonymous in most contexts. Because of the development of a new means for amplification this is no longer the case, and therefore we see a possible shift from (near-)synonymy to superordination/subordination.

The question is whether 'cloning' is still going to be used as a synonym of 'amplification' after the invention of PCR. Cloning is sometimes found as a synonym of 'amplifying' or 'amplification':,

"Applications of PCR technology are many and diverse. It can be used to clone specific sequences, although in many cases it is in fact not necessary to do this, as enough material for subsequent manipulations may be produced by the PCR process itself. It can be used to clone genes from one organism by using priming sequences from another, if some sequence data are available for the gene in question." (Nicholl,1994:102)

but it is at the same time a hyponym, as shown in :

\begin{abstract}
"Amplifying DNA. Most of the techniques currently used to analyze a segment of DNA require the availability of many copies of the segment. Two methods for 'amplifying' a DNA segment are now at hand: molecular cloning, which was developed in the 1970s, and the polymerase chain reaction (PCR), which was developed less than a decade ago." (Cooper, 1994:58)
\end{abstract}

This is a typical example of a situation where an existing term might extend its meaning, due to new inventions or developments. So, 'cloning' might extend its meaning and the new technique (PCR) might be classified under 'cloning', referring to a new method (technique) for cloning. But an alternative choice is possible, as we shall see. 
The two possible interpretations of how PCR relates to other concepts/categories in the domain which seem to be competing in the discourse of specialists can be visualized as in figures 12 and 13 .

\begin{tabular}{|l||}
\hline \hline Techniques (methods) for the amplification of DNA fragments: \\
\hline a. methods for molecular cloning \\
1. plasmid cloning \\
2. phage cloning \\
3. cosmid cloning \\
4. YAC cloning \\
\hline b. reverse transcription \\
\hline c. PCR \\
\hline
\end{tabular}

Figure 12: The first of the two competing interpretations of the meaning relationship between molecular cloning and PCR.

\begin{tabular}{||l||}
\hline \hline Techniques (methods) for the amplification of DNA fragments \\
\hline \hline a. methods for molecular cloning \\
\hline 1. plasmid cloning \\
\hline 2. phage cloning \\
\hline 3. cosmid cloning \\
4. YAC cloning \\
\hline 5. PCR \\
\hline b. reverse transcription \\
\hline
\end{tabular}

Figure 13: The second of the two competing interpretations of the meaning relationship between molecular cloning and PCR.

In the second interpretation 'cloning' underwent meaning extension as PCR is considered a type of cloning. For some authors, PCR is described as an alternative way of amplification next to cloning and the use of reverse transcriptase. (figure 12):

example 1

"DNA Amplification. Suppose we use the same restriction enzyme to cut plasmids and a chromosome. When the chromosomal fragments are cut plasmids are mixed together, they base-pair at random at their sticky ends. By using another enzyme, DNA ligase, the base pairing can be made permanent. 
We now have a DNA library - a collection of DNA fragments produced by restriction enzymes and incorporated into plasmids. We can insert the DNA library into bacteria or host cells for amplification. In other words, after repeated replications and divisions of the host cells, we end up with cloned DNA - multiple, identical copies of DNA fragments from the original chromosome.

DNA amplification can occur through other methods besides cloning. For example, single-stranded mRNA can serve as a template for assembling a DNA strand that is identical in sequence to some desired gene. The assembly requires a special viral enzyme, reverse transcriptase. After the "hybrid" DNA/RNA molecule is assembled, the RNA strand is degraded. Other enzymes convert the remaining strand of DNA to double-stranded form. Any DNA molecule "copied" from mRNA is known as cDNA.

Today, the polymerase chain reaction is the most commonly used method of DNA amplification. With this method, the gene of interest is split into two single strands, which enzymes then copy over and over to produce millions of copies of DNA containing that gene." (Starr, 1991:165)

"A DNA clone is any DNA sequence that has been amplified in dividing cells. DNA sequences also can be amplified in test tubes by the polymerase chain reaction." (Starr, 1991:169)

\section{example 2}

"Polymerase chain reaction (PCR), a technique that allows a DNA fragment to be analysed without having to be cloned first." (Hodson, 1992:207)

\section{example 3}

"The polymerase chain reaction technique (PCR) was devised by Kary Mullis in the mid-1980s and, like DNA sequencing, has revolutionarized molecular genetics by making possible a whole new approach to the study and analysis of genes. A major problem in analyzing genes is that they are rare targets in a complex genome that in mammals may contain as many as 100,000 genes. Many of the techniques in molecular genetics are concerned with overcoming this problem. These techniques are very timeconsuming, involving cloning and methods for detecting specific DNA sequences. The polymerase chain reaction has changed all this by enabling us to produce enormous numbers of copies of a specific DNA sequence without resorting to cloning." (Watson et al., 1992:79)

\section{example 4}

"The polymerase chain reaction $(P C R)$ is an in vitro method for $\underline{s e-}$ lectively amplifying, or synthesizing millions of copies of a short region of a DNA molecule. The reaction is carried out enzymatically in a test tube and has been successfully applied to regions as small as 100 base pairs and as large as 6000 base pairs. In contrast, DNA clo- 
ning is a nonselective in vivo method for replicating DNA fragments within bacterial or yeast cells. Cloned fragments range in length from several hundred to a million base pairs." (Cooper, 1994:128)

In the glossary at the end of Cooper's book it is made clear that the term cloning is only valid for "the production of many identical copies of a DNA fragment" by means of a cloning vector and a host cell. In the polymerase chain reaction a different process is involved:

"molecular cloning: The production of many identical copies of a DNA fragment by inserting the fragment into a cloning vector and propagating the resulting recombinant vector in a host cell."( Cooper, 1994:334)

"polymerase chain reaction (PCR): An in-vitro process for producing many millions of copies of a DNA fragment. The process involves successive repetitions of a series of reactions and, when applied to a sample containing many different DNA fragments, can amplify one selected fragment." (Cooper, 1994:335)

Other authors con sider PCR to be one possible cloning method (figure 13):

example 1

"Traditional cloning of small DNA fragments is being supplanted for many purposes by PCR, which can be regarded as in vitro cloning." (Green, 1991:876)

\section{example 2}

"PCR can also be used to clone genes, if two suitable primers can be made, and to select the correct gene construct from a mixture of constructs when making a synthetic gene: the use of PCR in cloning is very widespread." (Bains, 1993:242)

\section{example 3}

"Applications of PCR technology are many and diverse. It can be used to clone specific sequences, although in many cases it is in fact not necessary to do this, as enough material for subsequent manipulations may be produced by the PCR process itself. It can be used to clone genes from one organism by using priming sequences from another, if some sequence data are available for the gene in question." (Nicholl, 1994:102)

In specialised language cloning became so overloaded that it shifted into the generic or the specific class and was replaced by amplification. This because the emphasis was more and more on the 'large number of copies'-element instead of on the 'identical copy'-element. The 'identical copy'-core was not lost but was shifted in general language usage. 
Our data show that the semantic overloadedness seems to get solved in the following ways: generic shifting of clone from an LSP term to a general word and generic posting in LSP (amplification).

\section{First aspect: cloning shifts from a term (LSP) to a word (LGP)}

The metaphorical transfer of cloning

"The word 'clone' has entered the vernacular; it can be found in newspaper articles, in novels and in poems, and it is heard on radio and television. Often it denotes a single, perfect copy of something - a person, an animal, an idea - but, this is not the way in which biologists generally use the word.” (Berg \& Singer, 1992:89)

The figurative extension "exact duplicate, carbon copy, replica" is first recorded about 1978.'(Barnhart, 1988:181). The lexeme 'clone' got a new sense or meaning extension during the eighties.

"arose during the eighties, as a number of microcomputer manufacturers attempted to undercut the very successful IBM personal computer (and later its successor, the PS2)." (The Oxford Dictionary of New Words, 1991:64)

"a computer which deliberately simulates the features and the facilities of a more expensive computer; especially, a copy of the IBM PC." (The Oxford Dictionary of New Words, 1991:64)

The new sense of clone is described as:

"a specialization of the figurative sense of clone which originated in science fiction: from the early seventies, , a clone was a person or animal that had developed from a single somatic cell of its parent and was therefore genetically an identical copy. The computer clones were designed to be identical in capability to the models that inspired them (and, in particular, to run the same software)" (The Oxford Dictionary of New Words, 1991:64)

In the metaphorising process from the domain of biology to the domain of computer language the new 'value-added' meaning component is the cut price of the computer clones, which in its turn makes a new shifted meaning extension possible, as the lexeme is now also

'widely used for other cut-price copies (for example, of cars and cameras

as well as other computers).' (The Oxf. Dict. of New Words, 1991:64)

The criminal activity of providing mobile phones with the stolen number of a paying customer is called phone cloning, and the offending apparatus is called a clone phone. To clone a phone is the action of 'rechipping' a mobile phone with another number which belongs to 
someone else. This can be done after a suitable mobile phone number has been 'scanned' by some sophisticated electronic device. (Channel 4 News Bulletin 18 April 1995)

Cloning is an interesting case when considered in the semantic triangle system. It is subject to complicated mechanisms which are the result of the changing of the world, the rule system of language and the understanding of both the world and language by the human mind. It is clearly a category which can not be subjected to the rule of univocity.

\section{Second aspect: generic posting}

We are witnessing generic posting. By this we mean that the concept of cloning as a process being applied to a wider range of objects, then becomes generic for this kind of process while the more specific processes of duplicating plants, animals, etc. for the moment retain the word but may eventually develop their own. The result is that we have at least temporarily, a broad common concept called 'cloning', which applies to all forms. Next to it we have separate more specific concepts, with their own features, but still called 'cloning'. These concepts have their own partially common and partially distinct subconcepts, which will have distinct names and some names in common. This results in homonomy which may eventually be eliminated when techniques develop sufficient distinctiveness as their own specialists are working on them. The concept 'cloning' and its parallel 'clone' is then likely to remain as a general abstraction, a superordinate term, becoming broader and more vague as more detailed concepts spring up under this umbrella. At the same time, for contexts where precision really matters a different sort of generic posting occurs: amplification can be a generic term for both cloning and PCR.

We suppose that diversification of terminology begins when groups of specialists see the need for clearer differentiation.

Eventually scientists discover that the generic concept 'clone' no longer serves a useful purpose and then rewrite history, telling us that certain terms were originally wrongly used or wrongly understood and that for the current state of knowledge a new terminology will make the differences clearer. Such work may then lead to further splits, this time between the popular name for a group of processes and the scientific names which signify that these processes have little in common, or not enough, at least, to be united by a superordinate concept. 
We can conclude that there is ample evidence in this story of molecular cloning and PCR for the functionality of polysemy in the interplay of the three elements of the semantic triangle.

\subsection{2. (Near-) synonymy exists because the mechanisms for naming can trigger several possible lexicalisations.}

Slightly different perspectives results in near-synonyms. The univocity ideal of traditional Terminology consists of trying to eliminate some of the near-synonyms and indicating a preferred term. The underlying idea is that to have several terms for the same concept/category is a bad thing as it implies an impediment for unambiguous communication. The functional aspect of synonymy in a discourse community is overlooked.

Starting from the example of Southern blotting we can in the first place illustrate the functionality of synonymy and in the second place show that the reason why synonymy is functional may be that the different elements which are at the basis of lexicalisation were present in the initial situation when the technique was being developed.

\section{The functionality of synonymy.}

What is Southern blotting or Southern transfer or Southern hybridisation, and second why is this synonymy functional?

"Southern blotting is the commonly used term for the technique developed by E. M. Southern which involves the "transfer of single-stranded, restricted DNA fragments (=Southern transfer), separated in an agarose gel, to the nitrocellulose filter (or other binding matrix) which is then analyzed by hybridization to radioactive or biotinylated single-stranded DNA or RNA probes. The hybrids are detected by autoradiography or a color change, respectively. S.b. reveals details of sequence organization." (Rieger, 1991:454-5)

In a paragraph entitled "Probes to find cloned genes" we find the following description of Nucleic Acid Hybridization:

"Nucleic Acid Hybridization. Under the appropriate conditions two complementary single-stranded nucleic acids will spontaneously form base pairs and become double-stranded. If single-stranded, nonradioactive DNA is fixed tightly to a filter and then incubated in a solution containing single-stranded, radioactive DNA, double-stranded regions will form where the two types of DNA have complementary nucleotide sequences; the radioactive DNA will become indirectly bound to the filter through its 
attachment to a specific region of nonradioactive DNA. By measuring the amount of radioactivity bound to the filter, one can estimate the relatedness between two DNA's." (Drlica,1984:68)

In Drlica, the process of what is commonly known as Southern blotting is described but the term is not introduced, instead the hyperonym hybridization is used.

\section{As Grinsted and Bennett (1988:150) write: “}

The general technique to determine homology is hybridization, in which single-stranded DNA reanneals with complementary strands. Singlestranded test DNA is annealed with labelled single-stranded 'probe' DNA and the mixture then assayed for the presence of double-stranded labelled hybrid DNA. The amount and the stability of this will be a measure of the degree of homology between the test and the probe. In the case of fragments in a gel, the aim is to hybridize each of the them to a probe. One could hybridize each of the fragments and then hybridize them separately, but it is simpler to do all of the hybridizations together. This is achieved by denaturing the fragments in the gel (i.e. making them single-stranded) and then transferring them to a filter to which they are irreversibly bound. This is called a Southern transfer, after the inventor of the technique. (It is also called 'blotting', because of the details of the technique.) The filter is then incubated with labelled probe DNA, which hybridizes with homologous sequences; unhybridized probe is then washed away. Therefore the only label left on the filter should have hybridized to the test fragments. This can be detected by autoradiography and, since the fragments on the filter retain the same relative positions to each other as in the original gel, comparison of the position of the label on the filter and the photograph of the gel shows which fragments have homology with the probe."

\begin{tabular}{|l|l|}
\hline & motivation \\
\hline Southern blotting & the result of the technique is a blot on a filter \\
\hline Southern transfer & $\begin{array}{l}\text { the process of transferring the denatured (single } \\
\text { stranded) fragments from a gel to a filter }\end{array}$ \\
\hline Southern hybridisation & $\begin{array}{l}\text { the principle of the technique: single stranded } \\
\text { DNA reanneals with complementary strands }\end{array}$ \\
\hline
\end{tabular}

Figure 14: the motivation for the synonymous naming of Southern's technique.

The naming of Southern's technique is motivated by (at least) three aspects of the (encyclopaedic) information concerning the technique. 
Depending on which of the three elements a language user wants to stress in a particular context the use of one or another of the synonyms can be appropriate for more nuanced communication.

\section{The reason why synonymy is functional shows in the presence of the elements for alternative motivated names in the original texts on the method.}

E.M. Southern described his technique in two articles: "Detection of Specific Sequences Among DNA Fragments Separated by Gel Electrophoresis.” (1975) and 'Gel Electrophoresis.' (1979).

Southern does not refer to his own technique with 'Southern blotting'. Modesty or 'good manners' must be the explanation. In the 1979volume of Methods in Enzymology, in which Southern publishes his second well-known article, he does not use the term Southern blotting for his own method whereas other authors in the same volume consistently do. e.g.:

Szostak, J. et al. "Hybridization with Synthetic Oligonucleotides":

"In this chapter we describe procedures for the use of synthetic oligonucleotides for Southern blot experiments and gene bank screening, and demonstrate the effect of various mismatches on the efficiency of hybridization." (420)

"DNA fragments were transferred to nitrocellulose paper (Schleicher and Schuell) by the blotting procedure of Southern (...)." (421)

To refer to one's own method is felt by Southern as 'something which cannot be done', apparently. His modesty also shows from the paragraph entitled "Detection of Specific Sequences." (157) in which he gives a survey of the methods available to identify a particular sequence in DNA fragments separated by gel electrophoresis; and mentions his own method in the last place, even though his method (the Southern blotting technique) chronologically was the first one developed in time (1975) (protein: 1976; RNA: 1977).

However, his summary description of his own method is very accurate and contains the three elements which served in naming the technique: transfer, blotting and hybridization.(157-58)

“(...) DNA may be transferred from the gel to a sheet of cellulose nitrate, retaining the original patterns. The sheet of cellulose nitrate is laid against the gel, and solvent blotted through it by stacking absorbent paper on top. DNA is carried out of the gel by the flow of solvent and trapped in the cel- 
lulose nitrate paper, which is subsequently used for hybridization using well-established methods."

So all the elements for naming Southern's technique Southern blotting, Southern transfer or Southern hybridization were present in his own description of the technique.

\subsubsection{The third aspect of the univocity ideal for terminology which wants to rule out figurative language and replace it by literal equivalents is untenable as figurative language has a function in the development of LSP.}

The objectivist structuralist credo of traditional Terminology offered no tools for dealing with metaphor and metonymy, which were treated as unwanted and belonging to the figurative language which had to be replaced by literal equivalents. Figurative language was avoided as it was an impediment for scientific i.e. logical thinking. Experientialism ventures to study the influence of especially metaphorical models on categorisation and understanding.

In contrast with objectivism in which reality and the understanding thereof is seen as objective, independent of language and disembodied, cognitive semantics sees understanding and categorisation as experiential, i.e. embodied and based on human interpretation.

As Johnson (1987) shows experientialism opens up perspectives for imagination and creative thinking in which language as a medium for cognition and for communication about this cognition has a position. Imaginative and creative thinking is often reflected in the use of metaphors.

Metaphor is not in the first place studied as a language phenomenon, "a deviant form of expression or a nonessential figure of speech" (Johnson, 1987:66), but as a fundamental process at the cognitive level, the non-propositional level at which metaphorical projections can be experientially creative. This non-propositional level we have referred to elsewhere as the metaphorical environment (Temmerman, 1995)

Metaphorical thinking in the life sciences shows in the metaphorical environments which appear to exist as non-propositional gestalts in the heads of the specialists. The tangible results of the metaphorical understanding of an environment are the metaphorical lexicalisations for many (new) categories in the discipline. 
Johnson and Lakoff (1980) in Metaphors we live by, and Lakoff (1987) in Women, Fire, and Dangereous Things, showed how metaphor is pervasive in everyday life, not just in language but in thought and action. Their thesis is that metaphor in language is possible because there are metaphors in the human conceptual system as "most of our normal conceptual system is metaphorically structured".

Metaphors are culturally grounded in our physical and cultural experience. Experiential 'gestalts' are multidimensional structured wholes which are the basic dimensions of our experience. We classify particular experiences in terms of experiential gestalts (Lakoff \& Johnson, 1980:82). Understanding takes place in terms of entire domains of experience and not in terms of isolated concepts.

A theory of human conceptual systems has to account for how concepts are a) grounded, b) structured, c) related) and d) defined (106). Unclearly structured concepts get structured in metaphor. 'Metaphor is one of our most important tools for trying to comprehend partially what cannot be comprehended totally.' (193)

They argue that our experience is structured holistically in terms of experiential gestalts. These gestalts have structure that is not arbitrary. Instead, the dimensions that characterize the structure of the gestalts emerge naturally from our experience. (224)

'Within the experientialist myth, understanding emerges from interaction, from constant negotiation with the environment and other people. It emerges in the following way: the nature of our bodies and our physical and cultural environment imposes a structure on our experience, in terms of natural dimensions of the sort we have discussed. Recurrent experience leads to the formation of categories, which are experiential gestalts with those natural dimensions. Such gestalts define coherence in our experience. We understand our experience directly when we see it as being structured coherently in terms of gestalts that have emerged directly from interaction with and in our environment. We understand experience metaphorically when we use a gestalt from one domain of experience to structure experience in another domain.' (230)

In studying the language of the life sciences we found ample evidence of gestalts of domains of experience which served to structure experience in the domain of the life sciences. In other words these source gestalts of domains of experience provided the underlying metaphorical environments in which progress was made in understanding and creating more and new aspects of the life sciences. 
Their is growth of understanding and knowledge through metaphorical reasoning. This metaphorical reasoning amounts to the understanding of a new fact, situation, process, or whatever type of category based on the imagined analogy between what one is trying to come to grips with, to understand, with something one knows and understands already. This inventive or creative capacity is made tangible in neolexicalisations. These neo-lexicalisations are functional in the process of understanding which is reflected in language.

To replace the denominations based on metaphor by literal language can only be defended by a Terminology which has its roots in objectivism. As soon as Terminology opens up to cognitivism it will show an interest in the function of figurative language like metaphor in the interaction between the world, language and the human mind, an interaction which aims at better understanding, i.e. progress.

The analogical reasoning of which the metaphorical naming of new categories with existing lexemes is the result, is rooted in human experience.

\section{Metaphorical environments as non-propositional gestalts give rise to neolexicalisations.}

In structuralist linguistics metaphor is treated as a type of neology at the level of the signifié (Tournier, 1985). Traditional terminology has considered metaphor as a figure of speech which has to be avoided in unambiguous scientific terminology .

The disciplines of the life sciences develop in cognitive frames or cognitive image schemata which can be seen as gestalts. In order to develop new ideas practitioners of the discipline of the life sciences will also take over existing cognitive frames or cognitive image schemata from domains of experience outside the life sciences. Whenever this happens a metaphorical environment is brought to life.

The point is that the metaphorical environment as a gestalt plays. This shows when we compare what is lexicalised of the metaphorical gestalt to what can be extended but is not necessarily giving rise to lexicalisation.

Underlying progress in the understanding of the mechanisms of life are a number of analogies which have given rise to lexicalisation and the development of a new lexical field based on specific metaphorical 
gestalt structures or analogy image schemata, of which the following are examples:.

- Genes are messages written in a language (the language metaphorical environment).

- The language of the genes is information which is programmed and can be processed by the cell (the electronic information processing metaphorical environment).

- Geneticists are explorers or discoverers of unknown territory (the explorers metaphorical environment). ${ }^{13}$

We have been treating this more extensively elsewhere (Temmerman, 1995). For our present purpose it should suffice to show that for the terminology which is a consequence of the language metaphorical environment it is pointless if not impossible to replace the metaphorical naming for a number of new concepts/categories by 'literal equivalents'. As the metaphor is part of the understanding of the terms in discourse.

In the following description we indicated all the lexicalisations which bear on the metaphorical environment in bold.

As Shapiro describes it (1991:4), the idea that our genetic plan is stored in letters has been around for a little more than a generation.

Before that, our ancestors were inspired by other imagined analogies which left their traces in language.

Remnants of a much older idea are still preserved in language as a type of verbal fossil: that heredity is preserved and transmitted by our blood. The thought has become so familiar that we do not even pause when we see such phrases as royal blood, bad blood, blood relative, blue blood, and mixed blood. The blood theory was first devised by Aristotle (384-322 B.C.) and others of that era.

For those who believed this idea, inheritance involved a blending of parental qualities, as in the mixture of two different liquids.

Linear text is different. It can be spliced but not blended. The child receives a selection of components from both parents. Some remain intact, while other traits from a parent may be lost entirely.

13 There are more metaphor catalysts we could concentrate on like the 'genetic manipulation is designing genes' analogy or the 'war analogy' in the application of genetic engineering methods in the 'fight' against disease. (see Liebert, 1993). 
We summarize the story of inheritance and indicate the lexicalisations which bear on the underlying language analogy in bold face (Hodson, 1992 \& Berg \& Singer, 1992).

The mechanisms of inheritance were discovered in 1866 by Gregor Mendel. For Mendel the 'factors' of inheritance (we now call them genes) were entirely abstract entities. Microscopes were by that time operating at magnifications of x 1000 or more. Structures in the cell nucleus were seen that were like coloured threads; they were named chromosomes (from the Greek for 'coloured bodies'). It was immediately realized that here was the reality behind Mendel's 'factors'.

Chromosome research became the focus of genetics. It was obvious that the chromosomes provided the physical basis for Mendel's mechanisms of inheritance, they could not be the same as Mendel's factors (genes) for the simple reason that there were not enough of them.

Although the behaviour of genes was becoming better and better understood, there was no information about their physical behaviour beyond the fact that they were located in a row along the chromosomes. It was clear that the genes were in some way carrying messages, and that in order to be self-perpetuating through cell divisions, the genes must be able to duplicate themselves accurately. But there was no theory about what chromosomes could be made of to give them these remarkable properties. Later experiments pointed out that the secret was in the DNA (deoxyribonucleic acid). Francis Crick and James Watson tackled the problem of DNA's double helical structure by building a scale model of wire and pieces of cardboard. The molecule was like a spiral staircase, with the steps made of pairs of bases (A (adenine) always joined to $\mathrm{T}$ (thymine), $\mathrm{C}$ (cytosine) always joined to $\mathrm{G}$ (guanine)) and the banisters made of sugar-phosphate chains.

What Crick and Watson had discovered was that DNA had a structure which allowed it to copy itself. Since A must be paired with T, and $\mathrm{C}$ with $\mathrm{G}$, it follows that, if a DNA molecule is split down the middle lengthwise, all the information is there to reconstitute the whole molecule again.

Crick and Watson's proposed structure for DNA also provided the explanation for how a gene works, in chemical terms. It was already known that a gene controls the production of a single protein. What the Crick-Watson model showed was how the gene could contain a mes- 
sage encoded in the sequence of letters which was the specification of which protein is to be made.

The coding structure of DNA does two things:

- It ensures that DNA is replicated to produce more DNA.

- It ensures that DNA is transcribed into RNA, which is then translated into protein.

\section{Transcription and translation}

When DNA makes a protein, it does so via an intermediate molecule called ribonucleic acid (RNA) which is very similar to DNA. RNA is usually in the form of a single strand. A molecule of RNA can be made to an exact and repeatable pattern by reading off the base sequence of a stretch of DNA; this process is called transcription. The strand of RNA produced in this way is known as messenger RNA, or mRNA, since it carries the message telling that protein is to be made from the particular stretch of DNA that was copied.

Sydney Brenner worked with Crick on deciphering the DNA code, and they discovered that it is written in 'words' of three letters. As there are four possible bases occurring in groups of three there are 64 (i.e. $4 \times 4 \times 4$ ) possible combinations, but only 20 amino acids to be coded for. It turned out that most amino acids are coded for by more than one codon, and that there are three codons which do not represent any amino acid but are 'stop' signals where the protein-coding message ends.

The code sequence of the DNA gene is used to build a molecule of messenger RNA; this is assembled by an enzyme called RNA polymerase, and this part of the process is called transcription.

There are also many molecules of a different kind of RNA known as transfer RNA (tRNA). Each tRNA molecule consists of only three bases. These three bases form an anticodon, and each of these matches on to the codon in the mRNA. This part of the process, known as translation, takes place on the ribosomes, which act as a sort of assembly frame for building proteins. The tRNA molecules form a line, and the amino acids join up in the specifies order to form the protein chain.

Once the analogy between genes and language is recognised the image schema or cognitive frame or gestalt of language is opened up for metaphorical transfer to the new understanding and naming of the scientific field of genetics. The language metaphorical environment starts showing its impact on thought and language. When dealing with the 
message in DNA writers rely on the existing vocabulary of everything which has to do with language and language processing. The analogy is also going to give rise to explicit lexicalisations:

- Genes are carrying messages.

- Genes must be able to duplicate. To duplicate is part of the image schema of language, in its aspect of writing.

- The structure of DNA allowed it to copy itself which results in a lexicalisation: 'DNA copying'.

- The message in the gene is determined by the sequence of letters. This results in the lexicalisations: to determine the sequence of the letters is a technique called sequencing.

- DNA is transcribed into RNA, which results in the lexicalisation: transcription.

- RNA is translated into protein, which results in the lexicalisation: translation.

- In the process called transcription the base sequence of a stretch of DNA is read off. The strand of RNA ... is lexicalised as messenger RNA since it carries the message telling that protein is to be made from the particular stretch of DNA that was to be copied.

- The DNA code is deciphered and written in words of three letters : codons.

\section{Two types of lexicalisations and inconsistencies.}

The 'lexicalisations' in the domain under construction, i.e. the domain of the structure of DNA are of two types:

- Existing words from the metaphorical environment frame get a new meaning, giving rise to polysemy as seen from the point of view of the word, or to metaphorical naming or metaphorisation as seen from the point of view of the new concept which is being named. e.g. transcription, translation, DNA copying, message.

- The source field of the analogy is used as a source of inspiration for creating new words which did not exist before and which were necessary to name a new phenomenon or concept in the target field. Codon is an example of this.

The equivalent of a codon in the image schema or cognitive frame of 'language' is, word, which raises the question why the new term codon was coined? 
Apparently, word was too vague and too general and imprecise to become a term. A codon is a word or a code consisting of 3 letters only. In order to be more precise word would have had to be specified like in 'three-letter word'.

Codon sounds more scientific in analogy with lots of other scientific words (also in the physical sciences) ending in '-on': electron, transposon, exon, intron, etc.., and codon is reminiscent of code (DNA code, amino acids to be coded for, etc.) and codon is shorter.

According to Rieger (1991:98) codon goes back to Crick (1963). He defines codon as

"any triplet of nucleotides (coding unit) in DNA or RNA (if RNA is the carrier of primary genetic information as in some viruses) that codes for a particular amino acid or signals the beginning or end of the message (anticodon) (...) Of the 64 possible codons in the genetic code, the mRNA triplets UAA 'ochre), UAG (amber), and UGA (opal), serve as terminator codons, $A U G$ and $G U G$ are initiator codons.

Synonymous (=degenerate) codons are different codons for the same amino acid (...). There are indications that reading of a given context may be influenced by mRNA sequences external to this codon (effect of the reading context on translation). Any base triplet which can encode any of two or more amino acids is called an ambiguous codon." (Rieger, 1991:981 ${ }^{14}$

In this fragment the metaphorical gestalt or environment is worked out further: whatever can be ascribed to word is metaphorically transferred to codon: a word can be synonymous, so can a codon, a word can be ambiguous, so can a codon, there may be an effect of the reading context on the translation of a word, the same is true for a codon.

In other sources (The New Penguin Dictionary. of Biology, 1990) the terminator codons are named nonsense codons, a denomination which can also be explained from the metaphorical environment, based on the language analogy.

This is strong evidence for the hypothesis that the metaphorical environment is an underlying image schema which is not necessarily fully expressed propositionally. The proof is that if one lexicalisation (codon) is not in line with the image schema which provides the analogy (language) this does not really disturb the analogy as the word codon is further expanded on as if it were a synonym of word, as is

14 The emphasis is mine. 
shown in the lexicalisations synonymous and ambiguous codons (analogy with synonymous and ambiguous words).

\section{Conclusion. The consequences for terminography}

We realised that it is possible to distinguish between two types of concepts: those which are fit for a description in accordance with the univocity principle of traditional Terminology and those which are not. Concepts of the first type appeared to be clear-cut and not to show characteristics of prototype structure. For categories which do show prototype structure the principle of univocity is impossible to apply. The reason is that the principle is not at all in accordance with the facts of conceptualisation, categorisation and naming in LSP. For several of the categories we studied, the principle of univocity appeared to be useless as polysemy, synonymy and figurative language showed to have their function in the coming into existence and the further development of these categories. Therefore we propose a diversification in the methodology of terminography. First one has to distinguish between different types of concepts/categories In case of a clear-cut concept the univocity principle of traditional Terminology may be applied in terminography. in case of a category showing characteristics of prototype structure methods and principles have to be developed for incorporating polysemy, synonymy, and figurative language in meaning description. In order to make this possible a revaluation of what is traditionally referred to as encyclopaedic information is essential.

The impossibility to apply the univocity principle for a number of concepts/categories is just one example of how the principles and methods of traditional Terminology are an impediment for a diversified and realistic description of categories in LSP.

\section{References}

Bains, W. (1993): Biotechnology from A to Z. Oxford: Oxford University Press.

The Barnhart Dictionary of Etymology (1988). W. Wilson.

Berg, P./Singer, M. (1992): The Language of Heredity. California: Blackwell Scientific Publications.

Cooper, N. (1994): The Human Genome Project. California: University Science books. Crick, F. 1(979): Split Genes and RNA Splicing. In: Science 204, 264-271.

Dictionary of Microbiology and Molecular Biology. 1987. New York: J. Wiley \& Sons. 
Doolittle, W. (1978): Genes in Pieces: were they ever together? In: Nature, 272, 581582.

Drlica, K. (1984): Understanding DNA and Gene Cloning. New York: John Willey and Sons.

Felber, H. (1984): Terminology Manual. Vienna: Infoterm.

Geeraerts, D. (1989a): Wat er in een woord zit. Leuven: Peeters.

Geeraerts, D. (1989b): Prospects and Problems of Prototype Theory. In: Linguistics, 274 (302), 587-661

Geeraerts, D. (1993): Cognitive Semantics and the History of Philosophical Epistemology. In: Geiger, R./Rudzka-Ostyn, B. (eds.): Conceptualizations and Mental Processing in Language. Berlin-New York: Mouton de Gruyter.

Gilbert, W. (1978): Why Genes in Pieces? In: Nature, 271, 501.

Green, P. (1991): Genome, Human. In: Encyclopedia of Human Biology, vol. 3, 869897.

Grinsted, J./Bennett, P. (1988): Analysis of Plasmid DNA with Restriction Endonucleases. In: Grinsted, J./Bennett, P. (eds.): Methods in Microbiology, Vol. 21.

Halliday, M.A.K. (1985): An Introduction to Functional Grammar. London: Edward Arnold.

Hawkes, N. (1991): Genetic Engineering. London: Franklin Watts.

Hodson, A. (1992): Essential Genetics. London: Bloomsbury.

Johnson, M. (1987): The Body in the Mind. Chicago/London: The University of Chicago Press.

Kleiber, G. (1990): La sémantique du prototype. Paris: Presses universitaires de France.

Lakoff, G./Johnson, M. (1980): Metaphors we Live By. Chicago: University of Chicago Press.

Lakoff, G. (1987): Women, Fire and Dangerous Things. Chicago: University of Chicago Press.

Laurén, C./Picht, H. (1993) (Hrsg.): Ausgewählte Texte zur Terminologie. Wien: Termnet. IITF Infoterm.

Lee, T. (1993): Gene Future. The Promise and Perils of the New Biology. New York: Plenum Press.

Lewin, B. (1983): Genes. New York: John Wiley and Sons.

Liebert, W.A. (1993): Reflecting Your Own Cognitive Models. The Lexicon of Metaphor-Models of a Science Team of AIDS-Research. Paper presented at the Third International Cognitive Linguistics Conference in Leuven, 18 to 23 July 1993.

Meyer, I. (1992): Knowledge Management for Terminology-Intensive Applications: Needs and Tools. In: Pustejovsky, J./Bergler, S. (eds.): Lexical Semantics and Knowledge Representation. Berlin: Springer Verlag, 21-37.

Nicholl, D. (1994): An Introduction to Genetic Engineering. Cambridge: Cambridge University Press. 
The Oxford Dictionary of New Words. A Popular Guide to Words in the News. 1991 Oxford/NewYork: Oxford University Press.

Rieger, R./Michaelis, A./Green, M. (1991): Glossary of Genetics. Classical and Molecular. New Dehli: Narosa Publishing House.

Shapiro, R. (1991): The Human Blueprint: the Race to Unlock the Secrets of our Genetic Script. New York: St. Martin's Press.

Southern, E. (1975): Detection of Specific Sequences among DNA Fragments Separated by Gel Electrophoresis. In: Journal of Molecular Biology, 98, 503-517.

Southern, E. (1979): Gel Electrophoresis. In: Methods in Enzymology, 68, 152-176.

Starr, C. (1991): Biotechnology: Concepts and Applications. Belmont CA: Wordsworth Inc.

Taylor, J. (1989): Linguistic categorization: Prototypes in Linguistic Theory. Oxford: Claredon Press.

Temmerman, R. (1995): The Process of Revitalisation of Old Words: "Splicing", a case study in the extension of reference. In: Terminology 2:1, 107-128

Temmerman, R. (1995): Meaning Relationships and How to Detect Them: the Case of Biotechnology. In: Proceedings Maastricht Conference on Translation and Meaning. 1995.

Temmerman, R. (1996a): The Process of (Neo-)lexicalisation: the Case of the Life Sciences. In: Proceedings Third International Terminology Meeting 19-20 April 1996. Centre de Terminologie de Bruxelles.

Temmerman, R. (1996b): Retrospect Lexicalisation: A Recurrent Phenomenon in the Lexicalisation Process of the Life Sciences. In: Euralex 96 Proceedings, 825-835.

Temmerman, R. (1996c): Why some Terms are more Fit for Standardisation than others. From Standardisation to Optimisation of Understanding. In: Steurs, F. (ed.): Terminology and Terminography in Relation to Translation. Amsterdam: Rodopi.

Temmerman, R. (1996d): Terminology: the Structuralist Tradition and the SocioCognitivist Future. In: Terminology. 3(2).

Temmerman, R./Simonis, F./Luyten, L. (1990): Terminologie: een methode. Leuven: Acco.

Tournier, J. (1985): Introduction descriptive à la lexicogénétique de l'anglais contemporain. Paris-Genève: Champion -Slatkine.

Watson, J. e.a. (1992): Recombinant DNA. 2nd ed., New York: W.H. Freeman \& Co.

Wüster, E. (1991): Einführung in die allgemeine Terminologielehre und terminologische Lexikographie. 3. Aufl. Bonn: Romanistischer Verlag.

Zawada, B./Swanepoel, P. (1994): On the Empirical Adequacy of Terminological Concept Theories. The Case for Prototype Theory. In: Terminology 1(2), 253-275. 
